\title{
Preliminary Phytochemical Screening, Acute Oral Toxicity and Anticonvulsant Activity of the Berries of Solanum nigrum Linn
}

\author{
Hoang Le Son ${ }^{1 *}$ and Phan Thi Hai Yen ${ }^{1}$ \\ ${ }^{1}$ School of Biotechnology, International University - Vietnam National University, Ho Chi Minh City, Vietnam \\ *For correspondence: Email: h/son@hcmiu.edu.vn; Tel: +84 908 311518; Fax: +84 837244271
}

Received: 15 November 2013

Revised accepted: 9 April 2014

\begin{abstract}
Purpose: To investigate the preliminary phytochemical properties, acute oral toxicity and anticonvulsant activity of the berries of Solanum nigrum Linn (S. nigrum)

Methods: Phytochemicals from the ethanol berry extract were screened by standard methods. Acute oral toxicity study was conducted as per Organisation for Economic Co-operation and Development (OECD) 425 guidelines while anticonvulsant activity was evaluated against pentylenetetrazole (PTZ)induced seizure in mice. The effect of the extract at dose levels of 50, 100, 200 and $300 \mathrm{mg} / \mathrm{kg}$ body weight was evaluated in an experimental mice model, using phenobarbital as positive control (100 $\mathrm{mg} / \mathrm{kg}$ p.o).

Results: Phytochemical screening revealed that the berries of S. nigrum contain carbohydrates, flavonoids, saponins, tannins, alkaloids, phenols and steroids. The oral median lethal dose of the extract was $3129 \mathrm{mg} / \mathrm{kg}$ body weight. The extract significantly delayed the latency of convulsion $(p<0.05)$ in PTZ-induced seizure mice in at the dose of $300 \mathrm{mg} / \mathrm{kg} \mathrm{p.o.} \mathrm{The} \mathrm{extract} \mathrm{also} \mathrm{reduced} \mathrm{the} \mathrm{frequency} \mathrm{of}$ convulsion and provided up to $100 \%$ protection (300 mg/kg p.o) against death.

Conclusion: The results obtained in this study suggest that the ethanol berry extract of Solanum nigrum is safe and possesses anticonvulsant activity in PTZ-induced seizure in mice.
\end{abstract}

Keywords: Solanum nigrum, Phytochemical, Anticonvulsant, Pentylenetetrazole, Lethal dose, Acute toxicity

Tropical Journal of Pharmaceutical Research is indexed by Science Citation Index (SciSearch), Scopus, International Pharmaceutical Abstract, Chemical Abstracts, Embase, Index Copernicus, EBSCO, African Index Medicus, JournalSeek, Journal Citation Reports/Science Edition, Directory of Open Access Journals (DOAJ), African Journal Online, Bioline International, Open-J-Gate and Pharmacy Abstracts

\section{INTRODUCTION}

Solanum nigrum (S. nigrum) is a widely distributed tropical plant. It is a medicinal plant commonly used in Africa in ethnomedicine to treat a wide range of disorders including epilepsy. The plant has been reported to have antiperiodic, antiphlogistic, diaphoretic, diuretic, emollient, febrifuge, narcotic, purgative and sedative properties [1].
Epilepsy is a brain disorder in which clusters of nerve cells, or neurons, in the brain sometimes signal abnormally. Neurons normally generate electrochemical impulses that act on other neurons, glands, and muscles to produce human thoughts, feelings, and actions. In epilepsy, the normal pattern of neuronal activity becomes disturbed, causing strange sensations, emotions, and behavior, or sometimes convulsions, muscle spasms, and loss of consciousness [2]. 
The incidence of epilepsy in developed countries is approximately 50 per 100,000 while that of developing countries is 100 per 100,000 [3]. According to an epidemiological report, epilepsy afflicts $0.44-0.55 \%$ of the population of Vietnam. However, only 29/189 patients are treated periodically with anti-epileptic drugs (AEDs). The missed treatment of epilepsy in Viet Nam is very high (84. 7 \%) [4].

Modern antiepileptic drugs (AEDs) are unable to control seizure in some patients and also possess adverse effects such as absence of hypersensitivity reactions, weight problems, and drug interactions that cause central nervous system toxicity [5]. It has been observed that the presently available AEDs are unable to control seizures effectively in as many as $25 \%$ of the patients [6]. The conventional antiepileptic agents like phenytoin, carbamazepine and sodium valproate carry with them several serious side effects notably neurotoxicity [7]. Since a majority of AEDs are consumed for life, coadministration of other drugs predisposes to the risk of drug interaction. Thus, it is necessary to investigate new antiepileptic agents that have significant potential for epilepsy treatment as well as are safe in terms of toxicity. Medicinal plants used in traditional medicine for the treatment of epilepsy have been scientifically proven to possess promising anticonvulsant activities in mouse models [8-10], and thus could be regarded as a source of novel and safe anticonvulsants. Our study was carried out to investigate a non-toxic plant which has a potential in treatment of epilepsy.

\section{EXPERIMENTAL}

\section{Plant materials}

The berries of $S$. nigrum were collected from a mountain in Krông Nô, Đắk Nông Province of Viet Nam in August 2012. The plant was identified by Associate Prof Dr Tran Van Minh of the Institute of Tropical Biology, Viet Nam. A voucher specimen was deposited in the herbarium of Applied Biochemistry laboratory, Department of Applied Chemistry, School of Biotechnology, International University, Viet Nam National University Ho Chi Minh City, Viet Nam with voucher no. HB-BIO-09-08-12.

\section{Chemicals}

Pentylenetetrazole (PTZ) was purchased from Sigma-Aldrich (St. Spruce, Saint Louis, MO 63103 , USA), $70 \%$ ethanol was procured from Shanghai Demand Chemical Co., Ltd.
Phenobarbital $\quad(100 \quad \mathrm{mg}, \quad$ Sanofi-Aventis industries, USA). All drugs/chemicals were prepared fresh in distilled water to the desired concentration.

\section{Animals}

Healthy Swiss mice Mus musculus var. Albino, weighing $25-30 \mathrm{~g}$, were procured from Pasteur Institute of Ho Chi Minh City. They were housed in clean cages and had free access to standard pallet diet and water ad libitum. During the experiment, the mice were kept in a controlled environment of $12 \mathrm{~h}$ light/dark cycle. All the animals were acclimatized to laboratory conditions for a week prior to commencement of the experiments. All the animal studies followed the guidelines enunciated in the "Guide for the Care and Use of Laboratory Animals" [11], as well as specific national laws where applicable.

\section{Preparation of $S$. nigrum ethanolic berry extract}

Fresh berries of $S$. nigrum were dried in drying oven at $80^{\circ} \mathrm{C}$ and ground into fine powder (hereafter referred to as powdered berry). The powdered berry $(25 \mathrm{~g})$ was defatted with $350 \mathrm{~mL}$ of $70 \%$ ethanol $\left(60-80{ }^{\circ} \mathrm{C}\right)$ in Soxhlet apparatus. The extract was then evaporated in vacuum to give a brownish residue. The residue, subsequently referred to as the extract, was stored in a refrigerator until required for further use.

\section{Phytochemical screening}

Phytochemical analysis of the extract was carried out for the detection of various constituents [12].

\section{Oral acute toxicity test}

Acute toxicity of the plant extract was carried out in vivo in healthy female albino mice weighing 25 - $30 \mathrm{~g}$, labeled individually. Prior to dosing, the mice were fasted overnight and the dose for each mouse was determined based on the body weight. Solutions of the dried extracts were prepared using distilled water. The study was conducted as per Organization of Economic Cooperation and Development (OECD/OCDE) Test Guidelines on Acute Oral Toxicity under a computer-guided Statistical ProgrammeAOT425statPgm, version 1.0. Up and Down protocol and classifying category of toxicity based on the provisions of the Globally Harmonized System of Classification and Labeling of Chemicals (GHS) as adopted by the United Nations Economic and Social Council in July 2003 were conducted. 


\section{Limit test}

Initially, the extract was administered to one animal in a single dose of $2,000 \mathrm{mg} / \mathrm{kg}$ by oral gavage using a feeding tube. After administration, food was withheld for $3-4 \mathrm{~h}$. The animal was observed once during the first $30 \mathrm{~min}$ after dosing, then periodically, during the first 24 h. As the animal was not dead, four additional animals were given the same dose and observed similarly. Two mice were found dead after oral administration of the extract. All the survived animals were then kept for 14 days for further observation.

Next, the extract was administered to one animal in a single dose of $5,000 \mathrm{mg} / \mathrm{kg}$. After administration, food was withheld for a further 3 $4 \mathrm{~h}$. The animal was observed once during the first $30 \mathrm{~min}$ after dosing, then periodically, during the first $24 \mathrm{~h}$. As the animal was not dead, two additional animals were given the same dose and observed similarly. When both animals died, two additional animals were given a dose of $5,000 \mathrm{mg} / \mathrm{kg}$, one at a time. When all the mice died, the main test was conducted.

\section{Main test}

Since there was no estimate of the berry extract's lethality available, starting dose was selected as $175 \mathrm{mg} / \mathrm{kg}$. A single animal was dosed in sequence at $48 \mathrm{~h}$ intervals. The test was terminated when stopping criteria "5 reversals occur in any 6 consecutive animals tested" was attained. The estimated $L^{2} D_{50}$ was calculated from the animal outcomes at termination point using the software programAOT425statpgm.

\section{Determination of anticonvulsant activity}

Mice were randomly divided into six groups of five mice each $(n=5)$. Group I which served as control received an equivalent amount of distilled water; groups II, III, IV, and V received the extract doses of $50,100,200$ and $300 \mathrm{mg} / \mathrm{kg}$, p.o., respectively, while group $\mathrm{VI}$ received phenobarbital (100 mg/kg p.o) as reference standard. All the extracts and standard drug were administered $60 \mathrm{~min}$ before the administration of PTZ (85 mg/kg i.p.) and the mice were observed for convulsions. The mice were immediately placed individually in a cage, observed and monitored to determine the latency and the frequency of convulsions for each mouse. Values were expressed in terms of mean \pm S.E.M. Manifestations of seizures were rated on a 6point scale according to Racine's scale, which is widely used in studies on animal models of epilepsy (Table 1) [13,14].

Table 1: Six-point scale for anticonvulsant activity

\begin{tabular}{|c|c|c|}
\hline Light seizures & $\begin{array}{l}\text { Intermediate } \\
\text { seizures }\end{array}$ & $\begin{array}{l}\text { Heavy } \\
\text { seizures }\end{array}$ \\
\hline $\begin{array}{l}\text { 0.5: Immobility, } \\
\text { piloerection, } \\
\text { salivation, narrowing } \\
\text { of eyes, face and } \\
\text { vibrissae twitching, } \\
\text { ear rubbing with } \\
\text { forepaws }\end{array}$ & $\begin{array}{l}\text { 1.5: Clonic move- } \\
\text { ments of forelimbs } \\
\text { and mild whole body } \\
\text { convul-sions, } \\
\text { exophthalmia, } \\
\text { aggressive behavior }\end{array}$ & $\begin{array}{l}\text { 2.5: Rearing } \\
\text { and falling, } \\
\text { eye conges- } \\
\text { tion }\end{array}$ \\
\hline $\begin{array}{l}\text { 1.0: Head nodding } \\
\text { and chewing } \\
\text { movements }\end{array}$ & $\begin{array}{l}\text { 2.0: Rearing and } \\
\text { running with } \\
\text { stronger tonic-clonic } \\
\text { motions including } \\
\text { hind limbs, tail } \\
\text { hypertension, lock } \\
\text { jaw }\end{array}$ & $\begin{array}{l}\text { 3.0: Loss of } \\
\text { postural } \\
\text { tone with } \\
\text { general } \\
\text { body rigidity }\end{array}$ \\
\hline
\end{tabular}

\section{Statistical analysis}

Mean \pm standard error of mean (SEM) of the data were computed. Analysis of the data was made using SPSS, version 16.0. The statistical tools used were one-way ANOVA and paired sample t-test. The level of significance applied was $p<0.05$.

\section{RESULTS}

\section{Phytochemical profile}

The ethanol berry extract of $S$. nigrum revealed the presence of carbohydrates, flavonoids, saponins, tannins, alkaloids, phenols and steroids (Table 2).

Table 2: Phytochemistry of the ethanolic berry extract of $S$. nigrum

\begin{tabular}{lll}
\hline $\begin{array}{l}\text { Phytochemical } \\
\text { constituents }\end{array}$ & Phytochemical test & Inference \\
\hline $\begin{array}{ll}\text { Carbohydrates } \\
\text { Flavonoids }\end{array}$ & Barfoed's test & + \\
& Chloroform & + \\
Saponins & Shinoda test & + \\
& Emulsion test & + \\
Tanins & Frothing test & + \\
Alkaloids & Derric chloride test & + \\
& Mayer's test & + \\
& Hydrochloric acid test & - \\
Phenols & Ethyl acetate & + \\
& Diethyl ether & - \\
Steroids & Chloroform & - \\
& Hexane & + \\
\hline
\end{tabular}

${ }^{*}+$ indicates positive test result; - indicates negative test result 


\section{Acute oral toxicity study}

Data collected from Acute Oral Toxicity test by Up-And-Down procedure was described in Table 3. After 14 days of observation, long-term outcomes were recorded and used to estimate $\mathrm{LD}_{50}$ value in Table 4.

Table 3: Dose progression and results

\begin{tabular}{lcccc}
\hline $\begin{array}{c}\text { Test } \\
\text { Seq. }\end{array}$ & $\begin{array}{c}\text { Animal } \\
\text { ID }\end{array}$ & $\begin{array}{c}\text { Dose } \\
(\mathbf{m g} / \mathbf{k g})\end{array}$ & $\begin{array}{c}\text { Short- } \\
\text { term }\end{array}$ & $\begin{array}{c}\text { Long- } \\
\text { term }\end{array}$ \\
\hline 1 & 1 & 175 & $\mathrm{O}$ & $\mathrm{O}$ \\
2 & 2 & 550 & $\mathrm{O}$ & $\mathrm{O}$ \\
3 & 3 & 1750 & $\mathrm{O}$ & $\mathrm{O}$ \\
4 & 4 & 5000 & $\mathrm{X}$ & $\mathrm{X}$ \\
5 & 5 & 1750 & $\mathrm{O}$ & $\mathrm{O}$ \\
6 & 6 & 5000 & $\mathrm{X}$ & $\mathrm{X}$ \\
7 & 7 & 1750 & $\mathrm{O}$ & $\mathrm{O}$ \\
8 & 8 & 5000 & $\mathrm{X}$ & $\mathrm{X}$ \\
\hline \\
(X Died, O = Survived); stopping criteria met: 5
\end{tabular}

Table 4: Summary of long-term results

\begin{tabular}{llll}
\hline Dose & $\mathbf{O}$ & $\mathbf{X}$ & Total \\
\hline 175 & 1 & 0 & 1 \\
550 & 1 & 0 & 1 \\
1750 & 3 & 0 & 3 \\
5000 & 0 & 3 & 3 \\
All dose & 5 & 3 & 8
\end{tabular}

Statistical estimate based on the long-term outcomes; estimated $L D_{50}=3129$ (based on an assumed sigma of 0.5); approximate $95 \%$ confidence interval is 1750 to 5000

The oral median lethal dose of the extract was estimated as $3129 \mathrm{mg} / \mathrm{kg}$ body weight allocated to category 5 based on acute toxicity by the oral route (Table 5). Thus, it was considered to be safe.

\section{Anticonvulsant activity of ethanol berry extract of $S$. nigrum}

The ethanol berry extract of $S$. nigrum significantly delayed the latency of convulsions in a dose-dependent manner in PTZ-induced seizure mice.

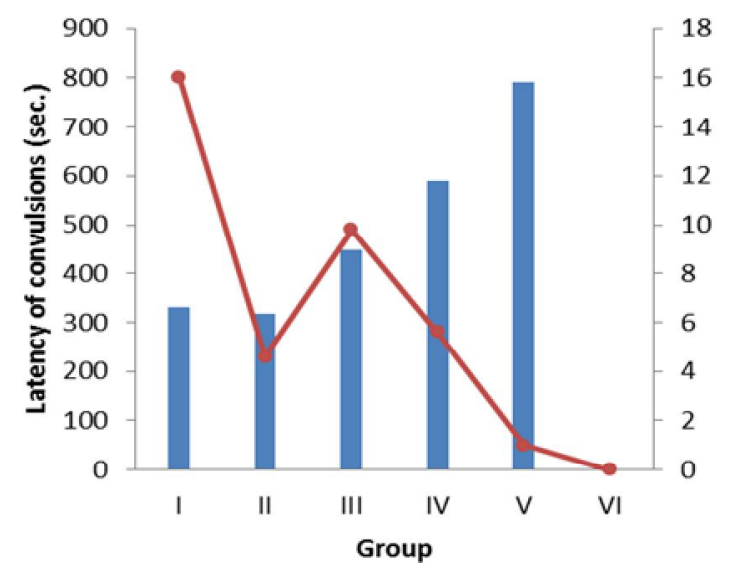

Fig 1: Effect of different doses of ethanolic berry extract of $S$. nigrum $(50,100,200,300 \mathrm{mg} / \mathrm{kg})$ on the latency of convulsions and the frequency of convulsions in mice. Note: Red curve denotes no. of re-occurrence of convulsion

The results are shown in Table 6 and Fig 1; for PTZ-induced seizure, the latency and reoccurrence of convulsions in group I (control) were $330.0 \pm 26.0$ and $16.0 \pm 1.1 \mathrm{sec}$, respectively.

Table 5: Acute toxicity hazard categories and (approximate) $L D_{50}$ values defining the respective categories*

\begin{tabular}{|c|c|c|c|c|c|}
\hline \multirow{2}{*}{$\begin{array}{l}\text { Acute oral } \\
\text { toxicity }\end{array}$} & \multicolumn{5}{|c|}{ Category } \\
\hline & 1 & 2 & 3 & 4 & 5 \\
\hline $\mathrm{LD}_{50}$ value & $\mathrm{LD}_{50} \leq 5 \mathrm{mg} / \mathrm{kg}$ & $\begin{array}{l}5 \mathrm{mg} / \mathrm{kg}<\mathrm{LD}_{50} \\
\leq 50 \mathrm{mg} / \mathrm{kg}\end{array}$ & $\begin{array}{l}50 \mathrm{mg} / \mathrm{kg}<L^{2} D_{50} \\
\leq 300 \mathrm{mg} / \mathrm{kg}\end{array}$ & $\begin{array}{l}300 \mathrm{mg} / \mathrm{kg}<L^{2} D_{50} \\
\leq 2000 \mathrm{mg} / \mathrm{kg}\end{array}$ & $\begin{array}{l}2000 \mathrm{mg} / \mathrm{kg}<\mathrm{LD}_{50} \\
\leq 5000 \mathrm{mg} / \mathrm{kg}\end{array}$ \\
\hline
\end{tabular}

${ }^{*}$ Chemical hazard classification and labeling: comparison of OPP requirements and the GHS

Table 6: $\quad$ Effect of ethanol berry extract of S. nigrum on PTZ-induced seizure mice

\begin{tabular}{llllll}
\hline $\begin{array}{l}\text { Group } \\
\text { (n=5) }\end{array}$ & $\begin{array}{l}\text { Latency of convulsion } \\
\text { (second) }\end{array}$ & $\begin{array}{l}\text { Frequency of } \\
\text { convulsions (time) }\end{array}$ & $\begin{array}{l}\text { No. of } \\
\text { convulsions }\end{array}$ & $\begin{array}{l}\text { No. of } \\
\text { deaths }\end{array}$ & $\begin{array}{l}\text { Protection } \\
\text { (\%) }\end{array}$ \\
\hline I & $330.00 \pm 26.0$ & $16.0 \pm 1.1$ & 5 & 5 & 0 \\
II & $317.60 \pm 73.2$ & $4.6 \pm 0.3$ & 5 & 5 & 0 \\
III & $447.20 \pm 50.8$ & $9.8 \pm 1.2$ & 5 & 5 & 0 \\
IV & $588.6 \pm 109.3$ & $5.6 \pm 2.6$ & 5 & 2 & 60 \\
V & $792.6^{*} \pm 157.7$ & $1.0 \pm 0.0$ & 5 & 0 & 100 \\
VI & 0 & 0 & 0 & 0 & 100 \\
\hline
\end{tabular}

${ }^{*}$ Each value represents mean \pm SEM; ${ }^{*} p<0.05$ compared with the control 
In group $\mathrm{V}, 300 \mathrm{mg} / \mathrm{kg}$ of the extract prolonged latency of seizures to $792.6 \pm 157.7$ and reduced frequency of seizures to $1.0 \pm 0.0 \mathrm{~s}$. All the animals in group I died, while in group $\mathrm{V}$ the mortality was $100 \%$. This is comparable to the values obtained for group VI (phenobarbital, reference) where $100 \%$ mortality was recorded. There were slight convulsions in mice of group $\mathrm{V}$ but were insignificant $(p<0.05)$. In group IV, protection against convulsion was $60 \%$, indicating the potential anticonvulsant activity of the extract at low concentration.

\section{DISCUSSION}

Data from this study show that $S$. nigrum significantly increases the latency and decreases the frequency of convulsions on PTZ-induced seizures. PTZ exerts its convulsant effect by inhibiting the activity of gamma amino butyric acid (GABA) at GABA-A receptors [15]. GABA is a major inhibitory neurotransmitter which is implicated in epilepsy. The enhancement and inhibition of the neurotransmission of GABA will attenuate and enhance convulsion, respectively [16]. Phenobarbital is a known conventional antiepileptic agent that generally inhibits sodium currents and enhances GABA-ergic inhibition. Since the extract delayed latency and reduced the reoccurrence of PTZ convulsions, it is probable that it may be interfering with gabaergic mechanism(s) to exert its anticonvulsant effect.

Phytochemical tests revealed that the extract contains various components. However, it is believed that the saponins and flavonoids present in $S$. nigrum might contribute to the anticonvulsant activity of this plant species as reported in previous studies $[17,18]$. However, further studies are needed to identify the specific compounds responsible for the anticonvulsant activity.

\section{CONCLUSION}

The ethanol extract of $S$. nigrum berry possesses an anticonvulsant activity against PTZ-induced seizure in mice and is safe for oral administration. These findings provide a basis for further pharmacological investigations that could lead to the development of new potential anticonvulsant compounds.

\section{ACKNOWLEDGEMENT}

This research was carried out with the strong support of International University, Vietnam National University, Ho Chi Minh City for which the authors would like to express their profound gratitude.

\section{REFERENCES}

1. Plant For A Future [Internet]. Solanum nigrum - L.; [cited 2013 Sep 19]. Available from: http://www.pfaf.org.

2. Government. Epilepsy (Seizures Disorders); [cited 2013 Sep 25]. Available at: http://www.medicinenet.com/ seizure/article.htm.

3. WHO. Epilepsy: Etiology, epidemiology and prognosis; [cited 2013 Sep 21]. Available from: www.who.int/entire/mediacentre/factsheets/fs165/en/.

4. Sức khỏe và Đời sống. WHO cam kết hỗ trợ Việt Nam phòng chống bệnh động kinh.; [cited 2013 Sep 13]. Available from: http://suckhoedoisong.vn/20130719 093934733p61c67/who-cam-ket-ho-tro-viet-namphong-chong-benh-dong-kinh.htm.

5. Dieter Schmidt. Drug treatment of epilepsy: Options and limitations. Epilepsy \& Behavior 2009; 15: 56-65.

6. Mattson RH. Drug treatment of partial epilepsy. Adv Neurol 1992; 57: 643-650.

7. Gupta YK, Malhotra J. Adenosinergic systemas an endogenous anticonvulsant mechanism. J Physiol Pharmacol 1997; 41: 329-343.

8. Sandabe UK, Onyelili PA, Chibuzo GA. Sedative and anticonvulsant effects of aqueous extract of Ficus sycamorus L. (Moraceae) stembark in rats. Vet Archiv. 2003; 72(2): 103-110.

9. Ma Eva G-T, Elisa T, Leonor L-M, Andrés N, Adelfo R-R, Adrián M. Anticonvulsant Effect of Annona diversifolia Saff. and Palmitone on Penicillin-induced Convulsive Activity. A Behavioral and EEG Study in Rats. Epilepsia. 2006;47(11):1810-1817.

10. John AOO. Anticonvulsant effect of Sclerocarya birrea (A. Rich.) Hochst. subsp. caffra (Sond.) Kokwaro (Anacardiaceae) stem-bark aqueous extract in mice. Jornal of Natural Medicines 2007; 61(1): 67-72.

11. Guide for the Care and Use of Laboratory Animals. NIH Publication No. 85-23. Revised 1985.

12. Harbone JB. Phytochemical Methods. A Guide to Modern Techniques of Plant Analysis. 2nd edn, Chapman and Hall, London, 1984: 84-274.

13. Setkowicz Z, Klak K, Janeczko K. Long term changes in postnatal susceptibility to pilocarpine induced seizures in rats exposed to gamma radiation at different stages of prenatal development. Epilepia, 2003; 44: 1267-1273.

14. Turski W.A., E.A. Cavalheiro, M. Schwarz, S.J. Czuczwar, Z. Kleinrok, L. Turski . Limbic seizures produced by pilocarpine in rats: Behavioural, electroencephalographic andneuropathological study. Behav. Brain Res 1983; 9(3): 315-335

15. DeSarro A, Cecchetti V, Fravolini V, Naccari F, Tabarrini $O$ and DeSarro G., Effects of novel 6desfluoroquinolones and classic quinolones on pentylenetetrazole-induced seizures in mice. 
Son \& Yen

Antimicrobial Agents and Chemotherapy, 1999; 43: 1729-1736.

16. Gale K. GABA and epilepsy: basic concepts from preclinical research, Epilepsia, 1992; 33, S3-S12.

17. Chauhan AK, Dobhal MP, Joshi BC. A review of medicinal plants showing anticonvulsant activity. Journal of Ethnopharmacology, 1988; 22: 11-23.
18. Giulia Di Carlo, Nicola Mascolo, Angelo A. Izzo, Francesco Capasso. Flavonoids: old and new aspects of a class of natural therapeutic drugs. Life sciences, 1999; 65(4): 337-353. 